\title{
A QUALITATIVE STUDY ON THE FACTORS INFLUENCING THE CHOICE OF WORKING AS A COMMERCIAL SEKS WORKERS AT BANDAR BARU, DELISERDANG, NORTH SUMATERA
}

\author{
Anita Loren Br Gurusinga, Kintoko Rochadi, Abdul Jalil Amri Arma
}

Faculty of Public Health, Universitas Sumatera Utara

\begin{abstract}
Background: The risk of HIV and other sexually transmitted diseases is high among persons who exchange sex for money or non-monetary items. This study aimed to decsribe the factors influencing the choice of working as a commercial seks workers (CSWs) at Bandar Baru, Deliserdang, North Sumatera.

Subjects and Method: A qualitative study was carried out at Bandar Baru Whore House, Deli Serdang, North Sumatera. A sample of informants was selected for this study, including CSWs and pimps. The study theme was factors influencing the choice of working as a CSW. The data were collected by in-depth interview and direct observation.

Results: The main reason for being a CSW was ease of earning money to support their lifestyle including consumption of illicit expensive drugs.

Conclusion: Commercial sex work is chosen to support costly lifestyle.
\end{abstract}

Keywords: commercial sex worker, lifestyle, HIV/AIDS

Correspondence:

Anita Loren Br Gurusinga. Faculty of Public Health, Universitas Suamtera Utara, Medan, North Sumatera. Email: anitaloren87@gmial.com.

Mobile: 081265556710 .

The 4th International Conference on Public Health Best Western Premier Hotel, Solo, Indonesia, August 29-30, 2018 | 152 https://doi.org/10.26911/theicph.2018.02.33 